\title{
KLAUS FERDINAND
}

\section{NOMADERS \\ FREMTIDSUDSIGTER}

\section{Beduiner i oliestaterne Qatar og Bahrain og pashtuner i Afghanistan}

Ændringsprocesser blandt pastorale nomader har i adskillige årtier været et vigtigt felt inden for antropologien. I det mellemøstlige område er det klart, at nomadisme ikke blot omfatter de kvægavlende nomader, men at der med udgangspunkt i den kvægavlende nomadisme findes en bred vifte af udviklinger og tilpasninger udmøntet $\mathrm{i}$ job i tilknytning til vandringsområdet i samspil med det omgivende samfund, som nomader enkeltvis eller i mindre og større grupper kan give sig i lag med. Denne udvidede nomadisme tager præg af de lokale eller regionale kulturelle og sociale omgivelser. I dette billede bliver det fornuftigvis et spørgsmål, hvornår man holder op med at tale om nomadisme og nomader. Dette belyses og diskuteres ud fra materialer fra de arabiske Golfstater Qatar og Bahrain og fra Afghanistan. I følge med olierigdommen og de efterfølgende drastiske moderniseringer i Golfen og andre arabiske olielande står nomaderne, beduinerne, her over for endeligt at forsvinde, men at „leve videre“ $\mathrm{i}$ de nationale museer $\mathrm{i}$ en ny rolle som et led i disse staters kulturelle arv og nationale identitet. I Afghanistan er forholdene meget anderledes, og nomadismen er endnu livskraftig. Det ser endda ud til, at krigen efter 1978 med ødelæggelser af landbrugsområder og politisk urolige forhold har medført, at nomadernes tidligere støtte fald i antal er standset, ja, at de måske ligefrem vokser i antal. Gennem deres afstamning tilhører pashtunnomaderne den statsbærende stammegruppe, uden at de af den grund her er blevet tildelt nogen særlig rolle som bærere af kulturel arv eller identitet. De er som andre nomader blevet opfattet som primitive „vilde“, som staten i civilisationens og moderniseringens navn måtte få gjort bofaste.

Som konsekvens af disse fremtidsudsigter må nomadestudier nødvendigvis fremover i højere grad atter blive historiske og vore etnografiske museumssamlinger endnu vigtigere som primære kilder. Det påhviler os derfor, at disse er så veldokumenterede som muligt, hvad de langtfra er i dag. Derfor bør der, mens tid er, igen foretages etnografisk „dataindsamling og redningsforskning“ vedrørende nomadekulturerne og ikke mindst den materielle kultur. Artiklen rundes af med at skitsere nogle tentative generaliteter vedrørende nomadernes materielle kultur i de behandlede områder.

I min brug af begrebet nomadisme følger jeg Khazanov (1981) og definerer det som livsformer, der i sidste instans alle er forbundet med den kvægavlende nomadisme og deres vandringsliv. ${ }^{1}$ Denne artikel har som baggrund erfaringer fra Bahrain i forbindelse med konsulentarbejde 1985-87 ved indretningen af det nye Nationalmuseum og erfarin- 
ger fra et mindre feltarbejde blandt Al Na'im og Al Murra beduiner i Qatar i 1959 (jf. Ferdinand 1993). Afghanske pashtunnomader har jeg haft gentagne feltophold blandt gennem 30 år (1953-1983); materialer vedrørende deres situation som flygtninge i Pakistan i 1980'erne inddrages også (jf. fx Pedersen 1994 og Frederiksen 1995-96).

\section{Al Na'im beduinerne på Bahrain og Qatar}

Qatar er en lav ørkenpræget halvø på Jyllands størrelse, som fra det arabiske fastland strækker sig ud i Golfen. Traditionelt bestod befolkningen af to erhvervsgrupper: fiskere og perlefiskere i landsbyer langs nord- og østkysten og kvægavlende beduiner i indlandet, hvor begge tilhørte forskellige arabiske stammegrupper; landbrugere fandtes derimod ikke. Beduinerne falder i to grupper: lokalprægede med korte årstidsvandringer i det nordlige Qatar, som Al Na'im og de langtvandrende kamelnomader, der kommer til det sydlige Qatar om vinteren fra Sydarabiens store sandområder. Det er særlig folk fra Al Murra stammen.

De kystnære Al Na'im beduiner har fascineret mig ved, at de tidligere foretog deres store årstidsflytning med både. Lorimers Gazetteer of the Persian Gulf fra 1908-15 er det eneste sted, hvor dette omtales på tryk. Det hedder her:

De nomadiske Na'îm uden for 'Omân anslås at tælle omkring 2.000 sjæle. Om vinteren bor de i Qatar, hovedsageligt i omegnen af Zubârah; i varmt vejr flytter de fleste af dem til Bahrain og danner lejre i den nordlige del af hovedøen, men nogle opslår sommerkvarterer nær Dôhah på Qatarhalvøen. Rygtet siger, at disse beduiner besidder i alt omkring 100 heste, 600 kameler, 1.000 får og 1.000 geder (Lorimer 1908, vol. II:1305).

Ikke uligt andre stammefolk i Mellemøsten er alle Al Na'im af samme oprindelse og falder i de samme navngivne undergrupper, hvad enten de hører til den bofaste hovedgruppe i Oman eller til nomaderne på Qatar og Bahrain. Politisk var de derimod ifølge Lorimer helt uden forbindelse med hinanden. Men nomaderne vidste, at deres forfædre for adskillige generationer siden var migreret fra Oman efter invitation fra Qatar for der at hjælpe til i en stammestrid (ibid.). Det blev starten på deres nære forbindelse med Bahrains regentfamilie Al Khalifa, der havde residens i byen Zubara i Nordvest-Qatar til den blev $\varnothing$ delagt i 1878 under krigen mod Qatars Al Thani sheik. Hos Lorimer hedder det videre:

\footnotetext{
Nogle af disse nordlige Na'îm er blevet perledykkere, men flertallet er stadig pastoralister, og deres eksistens afhænger af deres kvægbestand. Beduinerne fra de nordlige Na'îm holdes som lejetropper både af sheiken af Bahrain og af Âl Thâni sheikerne af Dôhah, og beskyttelsen af disse sheikdømmer anses for hovedsageligt at påhvile dem under perleflådens fravær fra hjemmet. Deres effektivitet og troværdighed er dog ikke hævet over enhver tvivl, og deres tilstedeværelse i Bahrain om sommeren er en kilde til irritation for de fredelige landbrugere fra andre stammer (op.cit.:1305-6).
}

Denne bådflytning hørte jeg om fra informanter på Bahrain i 1986-87; den var gået fra Zubara til landsbyerne Jau og Askar på Bahrains vestkyst. Det var en rigtig nomadeflytning med familier, småkvæg og kameler og i mindre omfang heste. På Bahrain tog beduinerne ophold nær brønde, hvor de havde traditionelle rettigheder, eller i palmebladshytter, barasti (eller mere korrekt arish) nær havet, som for eksempel på ubeboede små- 
øer. De græssede deres dyr i Bahrainøens sydlige ørken samt i palmehaveområdet mod nord, hvor de åbenbart havde været til almindelig gene for oaseboere. Med deres dyr var de beskæftiget i lasttransport, bl.a. af vand til byen. Disse beduiner havde som nævnt en særlig relation til Bahrains regent, hvilket må have været en væsentlig grund, måske den væsentligste, til deres komme til øen. De var desuden et klart eksempel på, at der mellem Golfens sheiker var og er konkurrence om knytte at beduiner til sig. Den specielle og nære relation mellem $\mathrm{Al} N \mathrm{Na}$ 'im og Bahrains sheikfamilie $\mathrm{Al}$ Khalifa går tilbage til deres tidligere bosættelse i samme område i Nordvestqatar omkring byen Zubara. Det var herfra Al Khalifaerne havde erobret Bahrain i 1783 i forbund med forskellige fastlands-arabiske stammefolk. Bahrain har stadig en fastboende gruppe af $\mathrm{Al} \mathrm{Na'im} \mathrm{med} \mathrm{fjerne} \mathrm{bånd}$ til deres pastorale baggrund. De bor på en lille $\emptyset$, som bærer deres navn Halat al-Na'im, nok en af de ovenfor omtalte øer, hvor de tog ophold om sommeren. Her var de blevet helt orienteret mod havet, og indtil for nylig deltog de i det årlige perlefiskeri omkring Bahrain. Nu er de handelsfolk og bureaukrater. I 1980'erne kom man ad en lav dæmning med asfaltvej til øen, hvor man tidligere havde kunnet vade over; den tidligere landsby havde nu forstadskarakter med ens byggede villaer, der var en gave til øens indbyggere fra Bahrains regent. En understregning af den nære forbindelse mellem de to parter.

I Rifa'a, hvor regenten og kronprinsen havde og stadig har paladser - oprindeligt i ørkenomgivelser - og holder deres offentlige modtagelser (madjlis), besøgte jeg en tidligere Al Na'im beduin fra Qatar. Han var falkoner for et medlem af sheikfamilien og holdt desuden nogle få kameler tilhørende ham selv og sheiken. Hans gæsterum var i sin udformning af beduintilsnit, ligesom som hans udendørs siddearrangement og træningsplads for falke var det. Andre Al Na'im mænd var også at træffe i Rifa'a, hvor de hørte til sheikens følge i forskellige tjenende funktioner. Det var i det hele taget typisk, at de var at finde her i sheikens tidligere „ørken“-residens.

I Bahrain findes der således stadig i dag $\mathrm{Al} \mathrm{Na'im} \mathrm{stammefolk} \mathrm{i} \mathrm{to} \mathrm{distinkte} \mathrm{grupper:}$ a) en gruppe, som ganske har brudt med deres traditionelle kvægnomadiske baggrund og også med den tidvis dertilhørende tilknytning til havet, i særdeleshed perlefiskeriet; og b) en gruppe eller enkeltindivider med en levende forbindelse til deres tidligere beduintilværelse og til deres stammefrænder i Qatar.

Fælles for dem begge er deres traditionelle klientforhold til Sheiken af Bahrain, overhovedet for $\mathrm{Al}$ Khalifa familien, som for øvrigt selv udviser levn fra deres beduinoprindelse og udstiller dem. Et forhold, som jeg senere vil vende tilbage til.

\section{Qatars beduiner i 1959}

I det nordvestlige Qatar i området omkring ruinbyen Zubara havde og har de kvægavlende $\mathrm{Al} \mathrm{Na}$ 'im beduiner deres boområde og græsningsrettigheder. Deres vandringer var få og stærkt begrænsede, i størrelse af 20-30 km. I vinterhalvåret boede de i stationære huslignende tillukkede åstagstelte af vævet gedehår og om sommeren i fladtagede sten-,,hytter“ nær brønde. I 1959, 11 år efter at olieproduktionen var startet i Qatar, bestod lejren af ikke fuldt funktionsdygtige nomadehushold af ældre mænd, kvinder, piger og smådrenge, jævnligt suppleret med lejede hyrder til at passe lejrens få kameler og småflokke af geder og får. Det daglige transportbehov klaredes af æsler, bl.a. til vandhentning, og rundt i lejrene var desuden malkekøer og til tider høns, som også passedes 
af kvinderne, og endelig var der af og til duer. Den traditionelle flytning blev foretaget med lejet lastbil og det var, som ved en traditionel beduinflytning, kvinderne, som havde en stor del af slæbet med lasten og telte. En enkelt Al Na'im var blevet lastbilejer og havde som levebrød at transportere arbejdere til arbejde. I øvrigt var de fleste af lejrens drenge hjemmefra på statslige kostskoler, mens de yngre mænd arbejdede for Oliekompagniet, en særlig ret de havde som statsborgere i Qatar. De ikke-arbejdende fik et månedligt underhold fra regenten, overhovedet for Al Thani sheikfamilien i Doha, et middel der brugtes i konkurrencen om at tiltrække og holde på beduiner. I Al Na'im lejre mødte vi ofte mænd, som havde været på Bahrain og været knyttet til regenten der. Vi mødte også folk, som klagede over deres månedlige ,pension“ og fortalte, at de var på vej til politikommandanten i Doha for at få den forhøjet (fra 500 til 1000 rupier om måneden, et betydeligt beløb dengang). Hvis det ikke skete, ville de tage flyveren til Bahrain og få pengene fra sheiken der! Pengerigelighed og de moderne tider var ved at slå igennem!

Al Murra beduinerne, som vi også arbejdede iblandt i 1959 i Sydqatar, havde også en særlig forbindelse til den regerende sheik. Den gruppe, vi boede sammen med, passede hans kameler, mens andre var ansat i politiet og enkelte arbejdede som chauffører enten i Qatar eller i Saudi-Arabien, som konkurrerede om at knytte beduiner til sig. Disse Al Murra var kamelnomader tilpasset livet i Sydarabiens store sandområder; tidligere havde overfald på karavaner, oasesamfund og svagere beduingrupper hørt med til deres eksistensgrundlag. Dette var slut i de stadig mere gennemkontrollerede og rige oliestater. Ja, rigdommen i disse meget traditionelt styrede tribale stater var blevet en ny ,niche " for beduinerne til at afbalancere det opståede og udækkede behov for ,tilskud" til deres ensidige kamelavlerøkonomi. De blev så at sige købt til fredeliggørelse og underordning! Dette system var også med til at vedligeholde, ja fastholde dem i en „,traditionel“ beduinlevevis.

Disse Al Murra beduiner flyttede i vinter-forårsperioden 1959 jævnligt lejr med deres sorte telte af en noget lettere og luftigere konstruktion end dem Al Na'imerne havde. Men også de måtte i den hede sommer bo fast nær brønde. Mens vi var blandt disse beduiner, så vi deres afhængighed og underordning udstillet i de høflighedsbesøg, som de ældste og mest betydningsfulde mænd i vor lejr aflagde i en sheiklejr i ørknen eller hos regenten i paladset nær Doha. Hertil bragte de friske trøfler fra ørknen, og de fik generøse gengaver i form af førsteklasses kokosreb til barduner, de fineste Basradadler (dadler var den daglige spise til kaffe) og en god kikkert. Det var sådan, at en god stammeleder opførte sig. Omkring paladset havde sheiken bygget en gæsteby, hvor de forskellige stammegrupper hver havde et antal huse til fri disposition: her kunne de bo gratis, når de ville besøge sheiken, eller de havde ærinde i byen. For disse ørkenbeduiner var afhængige af at få håndværks- og visse agerbrugsprodukter fra byen ganske som andre mellemøstlige nomader. Disse stammefolk var (er?) i sidste instans garanterne for statens og regentens sikkerhed, hans tro og loyale undersåtter og krigere! En stående hær! Men det var også klart, at olierigdommen og sheikens gavmildhed var med til at fastholde det ,traditionelle" beduinliv, som vi mødte det i 1959. Sheiken stod imidlertid også for modernisering og fremskridt (og kontrol), og året efter i 1960 startede regeringsbosættelsen af beduiner i landsbyer på Qatar.

Relationen mellem sheik og beduiner havde også sit rationale i, at sheikerne selv havde en beduinbaggrund og i 1959 stadig beduintræk i deres dagligliv. Adskillige af dem tilbragte de gode vintermåneder i faste teltlejre i ørknen i det sydlige Qatar på den 
samme plads år efter år. Gerne gemt i en lavning med læ mellem tornede buske. Vi besøgte en sådan lejr af sorte telte af sædvanlig $\mathrm{Al} \mathrm{Na}$ 'im type med gulv af flettede måtter, men de var langt større (det største var $10 \times 23 \mathrm{~m}$ i grundplan), rigere og helt anderledes udstyret end almindelige beduintelte med alskens sager, som hørte hjemme i en moderne byhusholdning. Her boede en gruppe sheikbrødre med familier og tjenestefolk. Ved siden af havde de et pavillontelt til gæster og en receptionsplads til besøgende. Den var anlagt i det fri med persiske tæpper og pudearrangementer på tre sider omkring et stort ildsted med fornemt kaffeudstyr parat til serveringen. Sheikerne havde desuden rideheste, ride- og malkekameler, en mindre flok geder og får til malkning og slagt, foruden falkonerer med jagtfalke og endelig mynder (saluqi) til jagt. Lejren var udstyret med en vognpark af limousiner og pick-up'er til forefaldende transport, og der var en tankbil til at sørge for frisk vand. Det var på alle måder et komfortabelt feriested!

Den form for „nomadisme“ minder om, hvordan rige, bofaste tidligere nomader i Afghanistan stadig tager i bjergene til faste lejrpladser for sommeren for hawa khori, som de siger, dvs. for luften og behagelighedens skyld (ordret ,luftspisning“).

Dette leder til spørgsmålet: hvornår er man ikke længere nomade? Eller retteligt: hvornår er det ikke længere meningsfuldt at kalde folk nomader? Er for eksempel $\mathrm{Al}$ Na'im falkoneren på Bahrain nomade? Det er han velsagtens! Men hvad med andre af sheikens følge af stammearabere, er de nomader? Det er de måske, men ikke nødvendigvis! Er Qatars sheiker nomader? Det kan man næppe sige mere, men på den anden side kunne de omtalte sheiker lettere end de fleste by- og oaseboere blive teltboende ørkenboere igen. Dette spørgsmål vender vi tilbage til.

\section{Pashtunnomader i Afghanistan}

For yderligere at belyse bredden i nomadebegrebet i samspillet med de bofaste omgivelser og ikke mindst de omsiggribende statsapparater vil jeg inddrage nogle forhold vedrørende nomadismen i Afghanistan, specielt blandt pashtunnomader i Østafghanistan. Forhold som hænger sammen med disse nomaders udnyttelse af en bred vifte af nicher i det omgivende samfund, som de møder under deres årstidsvandringer (Ferdinand 1969; Ferdinand et al. 1995-96:23; se fig. 1).

De østafghanske pashtunnomaders vandringer går og i særdeleshed gik mellem vinterområder i lavlandet i det østlige Afghanistan og hinsides grænsen til Pakistan i Tribal Area og Administrative Districts og sommerområder i det øst- og centralafghanske højland. I årets løb er de stedse nær bofaste agerbrugs- og bysamfund, hvorfra de erhverver de vigtige landbrugsprodukter hvede og majs, der som brød er deres hovedspise. De sælger kvægavlsprodukter (overskudsdyr, smørfedt og til tider osteprodukter o.l.) og evt. deres arbejdskraft som høstarbejdere, eller de involverer sig med deres kameler og æsler i transportarbejde. Disse lastdyr bruger de også i egne handelsentrepriser, som årstidsvandringerne mellem forskelligartede områder også giver udmærket mulighed for. Deres område har igennem århundreder, ja årtusinder været præget af statsdannelser, og pengeøkonomi er et gammelt træk i dette område, hvorigennem nogle af Asiens gamle karavaneveje gik.

Gennem statslige indgreb på begge sider af grænsen mellem Afghanistan og Britisk Indien (efter 1849)/Pakistan (efter 1947) er der langsomt sket en begrænsning i noma- 
dernes udfoldelsesmuligheder og antal. I Afghanistan skete dette også gennem bosættelsestiltag fra regeringens side, ikke mindst i det tidligere ikke-pashtunske Nordafghanistan. Men der var også forhold, der fremmede nomadismen, for eksempel regeringens underlæggelse af hazaraernes område (Hazarajat) i det centralafghanske højland i 1890'erne. Det gav de østafghanske nomader et nyt stort græsningsområde og efterfølgende en opblomstring af deres handelsaktiviteter i dette i handelsmæssig henseende jomfruelige område. Det medførte nye vandringsveje ikke alene fra Østafghanistan, men også fra nomadernes nye bosætningsområder i Nordafghanistan. Denne ekspansion skulle dog ikke vare ved. Afghanistans stigende modernisering fra slutningen af 1940 'erne, ikke mindst udbygningen af vejnettet og en voldsom udvidelse af lastbil- og bustrafikken, samt den ny, tættere administrative inddeling af landet i 28 provinser med nybygning af bybazarer omkring de administrative centre, medførte i løbet 1960'erne og 1970'erne drastiske ændringer for de østafghanske pashtunnomader og i særdeleshed for deres handelsvirksomhed. Medvirkende hertil var også de politiske spændinger mellem Pakistan og Afghanistan, der kulminerede i 1961-63 og resulterede i, at pakistanerne lukkede grænsen for de afghanske nomader, som ikke havde almindeligt pas og vaccinationspapirer på deres dyr. Tidligere havde nomaderne så godt som uhindret kunnet krydse grænsen. Dette kom til at ramme handelsnomadernes indkøb og transport (og til dels smugling) af varer fra Pakistan. Resultatet blev en drastisk omlægning af flytteveje og en $\emptyset$ get tilskyndelse til at søge bort fra nomadeerhvervet. Det var i særdeleshed tidligere Hazarajat-vandrende nomader, ikke mindst handelsnomader, som droppede ud og blev bofaste jordejere eller købmænd, evt. lastbilejere med basis i hovedstaden Kabul eller i andre byer.

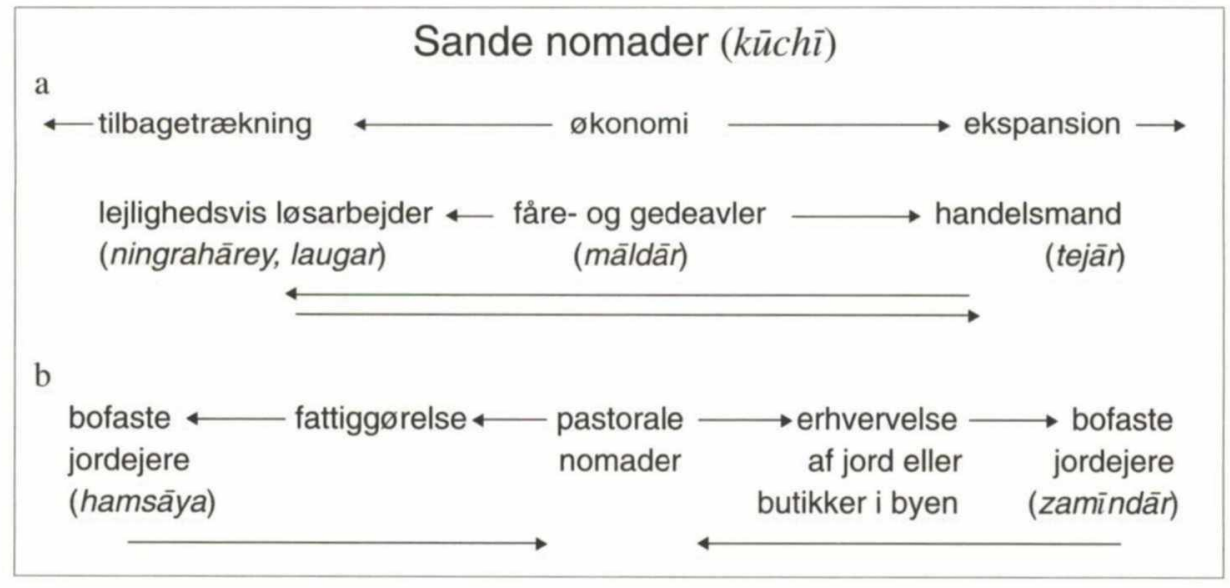

Fig.1 a) Pashtunnomadernes erhvervsmæssige kontinuum af muligheder og differentiering i Østafghanistan med udgangspunkt i de enkelte husholds dispositioner. „Casual work" for bofaste med høstarbejde, husbyggeri o.l. kaldes også „fattigarbejde“, gharîbî.

Fig. 1 b) Den almindelige bosættelsesproces blandt mellemøstlige nomader. Processen til højre mod bosættelse som jordejer eller bazarkøbmand har længe været den almindeligste i Østafghanistan. Processen mod en genetablering af den pastorale nomadisme er kendt over tid og har været almindelig i Vestafghanistan (se fig. 2). (Efter Ferdinand et al. 1995/96: 23, fig. 0,3a-b). 
Gorm Pedersen har overbevisende demonstreret dette for en gruppe handelsnomader (taghar af Ahmadzay, Ghilzay), som han studerede i 1975-76. I 1986 tog han til Pakistan og fandt der alle fra den taghargruppe, som han havde arbejdet blandt, 130 hushold $\mathrm{i}$ alt. Mest slående var det, at den rigeste og mest moderniserede undergruppe, som havde boet i et forstadsvillakvarter, var dem, som var blevet de mest nomadiske. Alle havde de genoptaget teltliv og årstidsvandringer. De var takket være deres rigdom i stand til at handle mere selvstændigt end andre og havde slået sig ned for sig selv, borte fra flygtningelejrene. Denne tilpasning havde ikke kunnet finde sted, hvis der i deres livsform havde været et afgørende brud i den kulturelle tradition. Deres nomadiske kultur var intakt. Disse taghar var med andre ord inden for det nomadiske kontinuum, som omtaltes ovenfor (jf. fig. 1), og de kunne atter have startet som kvægavlende nomader, havde græsningsmulighederne ikke været for begrænsede i Pakistan og konkurrencen om dem ikke været for hård. Denne gruppes flytninger blev derfor af en karakter, som den mere fornøjelsesprægede sommerflytning omtalt ovenfor, hvor hovedbegrundelsen var at slippe bort fra den uvante varme i deres nye omgivelser. De fik råd til det ved først at tære på deres medbragte kapital fra Kabul og dernæst ved at fortsætte deres handels- og transportvirksomhed inden for det pakistanske område. I 1997 rapporteres der om dem som meget succesfulde, ja inden for transportsektoren endda som dominerende. ${ }^{2}$

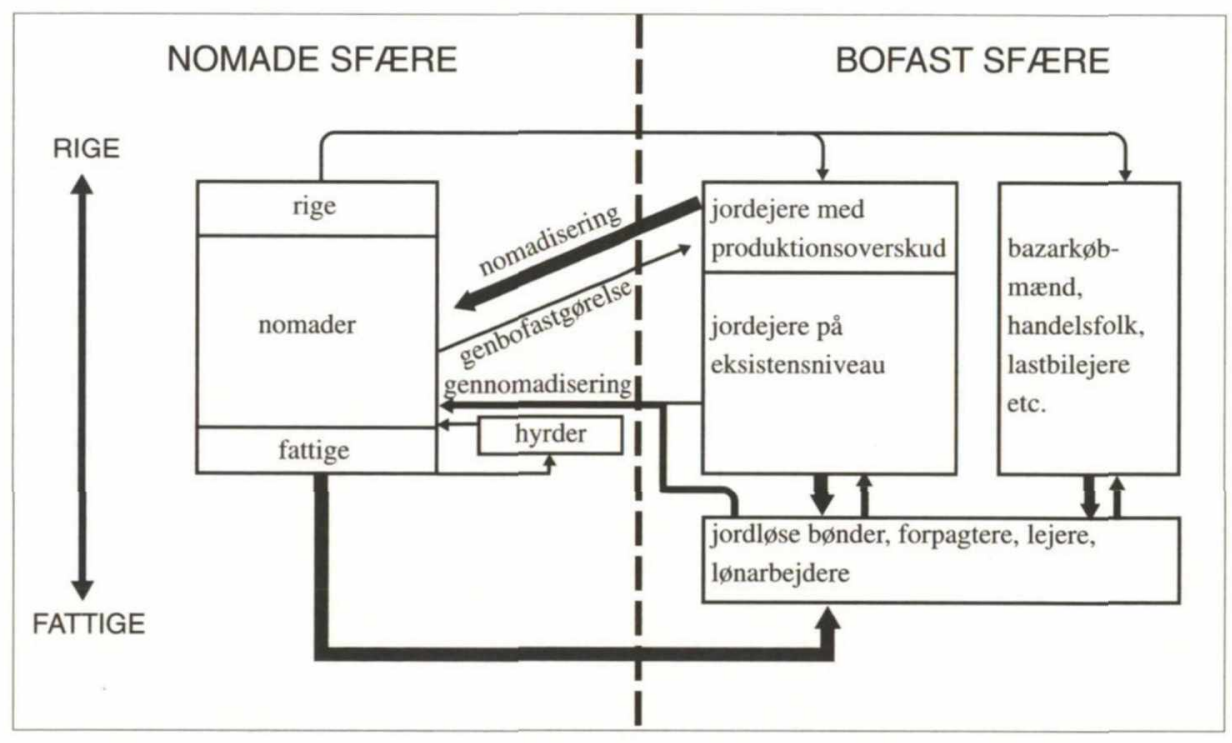

Fig. 2. Diagram over mobiliteten mellem den nomadiske og den bofaste sfære blandt pashtuner i Vestafghanistan. (Efter Glatzer 1982:75).

Den store proces med svingninger over tid mellem nomadisk kvægavl og bofast agerbrug i samspil med de naturgivne og kulturgivne sociopolitiske omgivelser, som kendes historisk fra det mellemøstlige område, kendes også fra Afghanistan. I nutiden i særdeleshed blandt duranninomader i Sydvest- og Vestafghanistan (Ferdinand 1969a; Glatzer 1977, 1982). I dette område er der en udbredt tradition for brug af „sorte telte“ i sommertiden også blandt landsbyboere, dvs. såkaldt halvbofasthed eller halvnomadisme, som 
kulturgeografer tidligere karakteriserede det. Fra Sydøstafghanistan er der fra ældre tid også eksempler på overgang til nomadisme; som for eksempel da en større gruppe bofaste pashtuner (kharotier) på grund af jordmangel blev nomadiske, hvad de er forblevet til nyeste tid (Elphinstone 1842 [1815], II:160; jf. Robinson 1934:143). Men ellers er det den modsatte proces med bofastgørelse af nomader, som har præget forholdene i Afghanistan de sidste 100-150 år. De ufredelige forhold, der har rådet i Afghanistan i de seneste to årtier, har igen vist nomadismens tilpasningsduelighed over for ændrede forhold. Mobiliteten og deres afhængighed af deres dyrs græsning gør dem mindre sårbare og mere overlevelsesduelige end stedbundne bønder, når ufred og mindre kontrollerede forhold hersker. Man kan måske endda under disse omstændigheder tale om en opblomstring af nomadeerhvervet. ${ }^{3}$ Tilsvarende opblomstring er dokumenteret fra Iran under 2. verdenskrig og efter shahens fald i 1978, hvor den stærke politiske kontrol i stammeområderne blev svækket (Beck 1980, 1984; Shafizadeh 1984).

Men der er dog markante forskelle mellem de afghanske pashtunnomader og de arabiske beduiner.

\section{Beduinerne i nyeste tid}

Da jeg sammen med Christel Braae arbejdede som konsulent for Bahrains Nationalmuseum, var det fra starten klart, at der skulle være en særlig sektion om beduiner. Men der var betydelige forskelle i opfattelsen af, hvad der skulle med i præsentationen af Bahrains etnografi og folkeliv. Vi mødte synspunktet i museumsstaben, at beduinerne egentlig slet ikke skulle med, for de var ikke bahrainier, og de betød intet for dem i dag! Andre havde den modsatte mening, for dem var arabere, beduiner og ørknen helt uadskillelige. Det gjaldt bl.a. medlemmer af regentfamilien, Al Khalifaerne, som stadig holdt visse beduintræk og levemåder i hævd. De havde og brugte således stadig stammemærke (wasm) på deres kameler. Til den sheiklige ,,beduinkultur“ hørte også avl af heste og hold af jagtfalke og jagtmynder (saluqi). Men i overensstemmelse med den almindelige arbejdssituation på Bahrain blev den største kamelflok passet af fremmed arbejdskraft fra Punjab. Mindre flokke passedes derimod stadig af rigtige beduiner, som $\mathrm{Al} \mathrm{Na'imer.}$

Mens man må regne med, at nomadismen vil fortsætte med at eksistere i Afghanistan og Pakistan i måske mange år endnu, så er det sandsynligt, at den vil forsvinde i Golfstaterne og i Saudi-Arabien inden for en overskuelig tid som følge af de omfattende ændringer som olierigdommen har bragt med sig. Men beduinen og hans nomadisme vil umiddelbart leve videre, i nye omgivelser og med nyt indhold: i museerne. Ikke på grund af vor faglige indsats, men som del af disse landes kulturelle arv og historie og som et $\emptyset$ nske fra disse overvejende autoritære tribale stater om at etablere deres egen politiske landeidentitet inden for rammerne af en fælles arabisk identitet (jf. Braae 1997). Beduinerne er nu udstillet på alle nationalmuseer i Golfstaterne, også, men mindre fremtrædende, i Saudi-Arabien, ${ }^{4}$ og vi finder dem dokumenteret som folkekultur i for eksempel museums- og folklorecentret Centre of Cultural Heritage i Manama, Bahrain, og i The Gulf States' Folklore Centre i Doha, Qatar, og andre steder.

For at runde billedet af, så møder vi et ekko fra beduintilværelsen i oliearbejdernes og de moderne byboeres weekendbilture med familien i ørknen med frokost, grill-udstyr, termokaffe, søde sager og dadler - om foråret med det særlige incitament at finde de højt 
priste trøfler. Og i de nationale heste- og kamelvæddeløb, i jagtturene med telt og bil med falkonerer og falke hjemme eller i udlandet, det være sig i Saudi-Arabien, Iran og nu også i Pakistan. Det er gennem disse traditionelle og nu nationale sportsaktiviteter, at båndet til „beduinfortiden“" særlig holdes i live.

I museumsgørelsen af beduinerne er tre synsvinkler eller områder værd at fremhæve: en populistisk med interesse for egen fortid, en professionel „objektiv“ overvejende historisk synsvinkel og endelig en politisk, hvis sigte er at etablere og fremme en national fællesfølelse og identitet. Disse tre er til dels blandede, men også, om end i vekslende grad, bundet til opdragelses- og uddannelsesmæssige mål. Vedrørende beduinfortiden og dens almene rolle for den arabiske fælleskultur er disse tre synsvinkler i overvejende grad i overensstemmelse med hinanden. Mindst nok i Bahrain.

Går vi herfra til Afghanistan, er forholdene der betydeligt anderledes. Nok hører pashtunnomaderne til den statsbærende og historisk helt dominerende etniske gruppe fra midten af 1700-tallet og frem til i dag. Men nomaderne har på ingen måde fået tillagt en særlig position. De er med i det politiske pashtunfællesskab, som statsmagten støttede sig til, og hvis sprog og kultur nød særlig fremme helt frem til revolutionen i 1978 og det efterfølgende kaos og krigen. Som nomader har de i visse situationer nydt regeringens bevågenhed, særlig i forhold til andre etniske grupper som for eksempel hazaraerne i Centralafghanistan. Men i almindelighed er de som andre stammefolk søgt kontrolleret til tider direkte bekæmpet - i statens almindelige del-og-hersk-politik vis-a-vis stammer, etniske grupper og andre mulige magtbaser. Staten accepterede og beskyttede nomaderne i deres rettigheder til vandringsveje, græsning, ja, lovgav så sent som i 1970 om det, men har egentlig fra grundlæggelsen af det moderne centralistiske afghanske statsapparat i slutningen af 1800-tallet principielt været anti-nomadisk og søgt at fremme pashtunnomadernes bosætning, gerne hvor det fremmede statens tilstræbte pashtunisering af landet. Betegnelsen ,vilde“ (wâshî) om pashtunnomader var det ikke ualmindeligt at støde på fra bofaste regeringsembedsmænd, og det selvom det var fra deres egne stammefrænder. Nomader og nomadisk levevis var i det hele taget ikke noget statsmagten gjorde noget særligt ud af med ganske få undtagelser. På ét officielt fotografi af kong Zaher Shah fra 1950'erne ses han iført en fornem filtkappe, som dem hans nomadiske stammefrænder af duranni stammekonfederationen i Sydafghanistan bærer. Men de færreste har nok set den etniske symbolik heri. I det officielle afghanske turistbureaus internationale markedsføring af Afghanistan har nomaderne kunnet bruges i folkloristiske fotografier. Ved nøjere granskning viser det sig at være en Kabulpige klædt i nomadekvindedragt. Nok har pashtunnomaderne i sidste instans afstamningsmæssigt forbindelse med kongemagten i Afghanistan, men de har ingen position, som tilnærmelsesvis ligner beduinernes placering i det arabiske samfund. På lignende vis har forholdene været i Persien, hvor det ene nomadedynasti har afløst det andet, uden at dette har ført til en særlig værdsættelse af nomadekulturen.

Dette leder til en afsluttende bemærkning. Siden de rigtige nomader, dvs. dem der, som de traditionelle arabiske beduiner i sidste instans er forbundet med kvægavl, kun synes at have en museumsfremtid og bliver historie, så mener jeg også, at vore studier må blive historiske. Som etnografer har vi, synes jeg, forpligtelsen til atter at gå i lag med „reddes-hvad-reddes-kan-etnografi“ (,salvage ethnography“), og her tænker jeg navnlig på museumsindsamling og på at skaffe dokumentation til vore museumssamlinger, foruden seriøst at analysere dem. 
Et meget stort arbejde er udført inden for feltet nomadiske studier i snart mange årtier, som for eksempel af The Commission on Nomadic Peoples (International Union of Anthropological and Ethnological Sciences) med dets tidsskrift Nomadic Peoples (oprindelig Newsletter 1977 ff.). De stater, som disse studier berører og vedrører, og dem, som er ansvarlige for den kulturelle arv, er allerede involveret, men jeg mener, at vi som professionelle fagkyndige må gå i lag med studier af den materielle kultur, tidligere et respekteret studiefelt, for derigennem at få bedre perspektiv på nomader og nomadisme og på de gennemgående ikke synderligt veldokumenterede sager i vore museer. Sagen er, at disse sager i stadig stigende grad vil blive primært kildemateriale i fremtidige nomadestudier, som er dømt til at blive historiske, sådan som vore studier også var engang. Det er ikke af ren nostalgi, at jeg foreslår en genoplivning af studier over materiel kultur. Det er fordi, jeg finder det vigtigt, før end det er for sent at få den nødvendige og gode dokumentation, og fordi jeg finder, at vi har forladt disse studier alt for tidligt, og uden at være sikre på, at de ville blive fortsat, endsige rimeligt afsluttet.

Til sidste vil jeg tentativt skitsere nogle resultater på baggrund af den materielle kultur hos beduiner og de østafghanske nomader (jf. Ferdinand under udgivelse). Den materielle kultur for disse nomader er kun til en vis grad specifik for dem, fordi:

1) Det meste eller en stor del af deres materielle genstande får de fra de omboende folk inden for deres årstidsområder eller under deres vandringer. Det være sig fra omvandrende handlende og håndværkere eller fra bofaste i landsbyer eller byer. I vid udstrækning erhverver de genstande eller materialer, som er specielle for den etniske gruppe, som de selv tilhører; men det er dog ikke nødvendigvis sådan, som det for eksempel ses i pashtunnomadernes sommerområder i Centralafghanistan eller i de forholdsvis nye vinterområder i Nordafghanistan. I øvrigt forekommer vinterområdet at være det udslagsgivende, hvad angår det materielle udstyr som redskaber, dragter og deres specifikke udformning, samt hvad angår mad o.l. I Nordafghanistan, i det såkaldte afghansk Turkistan, har derboende pashtuner og nomader fået et centralasiatisk, tyrkisk kulturelt præg i for eksempel mandsdragten, hvad der her også må betragtes som en praktisk foranstaltning.

2) Specifikt for nomaderne er genstande, som er forbundet med deres erhverv, kvægavlen, og flyttelivet. Det ses i deres boligform: bardunteltet af vævet gedehårsdug med tilhørende reb og bånd og i vid udstrækning også i udstyret til deres last- og ridedyr og eventuelle malkedyr, og i at redskaber og udstyr ofte er gjort bærbart med snore, reb og bånd. Det gælder også den udbredte brug af beholdere og poser af læder og skind fra husog jagtdyr, et træk som traditionelt har været almindeligt blandt beduiner, navnlig i det centrale og sydlige Arabien ikke fjernt fra et større afrikansk kulturelt læder- og skindområde. Det gælder desuden den mangfoldige brug af vævede og knyttede materialer (i visse områder filtede materialer) og af bånd og reb til praktiske og/eller dekorative formål i teknikker, som nomaderne deler med andre erhvervsgrupper inden for deres områder. Mens former og anvendelser i vid udstrækning er specielt for nomaderne.

Vedrørende de pastorale nomaders telttyper er de overordentlig stabile i udseende og struktur, og en bestemt form kan formodentligt have eksisteret i århundreder. Dette slutter jeg ud fra det forhold, at arabiske og afghanske teltformer hver for sig er præget af stor ensartethed, såvel regionalt som over tid. Inden for begge regioner har teltene således været uændret igennem hele 1900-tallet, og det gælder også for små detaljer i udformning og konstruktion, samtidig med at det er sikkert, at ingen nye teltformer er opstået. Teltformerne er både områdespecifikke og specifikke for bestemte etniske og tribale 
grupper. Reglen synes at være, at det er den dominerende gruppe inden for vinterområdet, som er udslagsgivende for den anvendte teltform og eventuel ændring af teltform for nye grupper, som kommer til et område. ${ }^{5}$

Den materielle kultur blandt disse mellemøstlige nomader er yderligere et eksempel på, at nomadiske samfund i dette område ikke udgør en kultur i sig selv, ja ofte heller ikke engang et eget samfund. Den materielle kultur er med til at understrege, at vi står over for en ,,del-kultur“, sådan Kroeber i sin tid har karakteriseret nomadesamfundene (Kroeber 1947). Men det er en ,del-kultur“, som har fået sit helt specielle præg fra kvægavl i kombination med flyttelivet. Men, det meste af deres materielle kultur deler nomaderne med de omboende folk, i særdeleshed med deres egne bofaste stammefrænder.

I Afghanistan har langsom modernisering, udbygning af landeveje og transportvæsenet, statslige indgreb o.l. sat stadig snævrere rammer for den nomadiske udfoldelse $\mathrm{i}$ årene op til revolutionen i 1978 og de drastiske omvæltninger og krig i de efterfølgende år. Denne urolige tid har givet eksempler på både fortsatte stærke begrænsninger i nomadernes liv og på en vis genopblomstring af nomadismen.

I De arabiske Golfstater er billedet anderledes. Olien har her grundlæggende ændret livsbetingelserne, og nomadismen står over for sit endeligt eller er nær derved. Men beduiner er stadig nærværende. Nationale institutioner som Museer og Centre for den kulturelle Arv (Heritage Centres) har givet nyt liv til beduinerne i en blanding af politiske, folkelige og professionelle interesser.

\section{Noter}

1. Det bliver mere og mere almindeligt i faglitteraturen at bruge begrebet nomade bredt og gøre flytte- eller vandringslivet til det bestemmende. Således kan man tale om nomadiske jægere og samlere, fiskere, vandrearbejdere, sigøjnere osv. Se fx Rao (1987) og Nomadic Peoples No. 36, 1996. Khazanov argumenterer herimod ud fra synspunktet, at nomadisme er et særligt fødeproducerende erhverv (Khazanov 1983:15).

2. Information fra Gorm Pedersen fra hans besøg i Peshawarområdet og i Østafghanistan efteråret 1997.

3. En mulig eller tilsyneladende vækst kan også skyldes, at den tidligere støtte afgang fra nomadeerhvervet til bofaste aktiviter er stoppet som følge af krigstilstanden, ødelæggelser af landbrugsjord m.v. Det er værd at berette, at danske etnografer har berettet om mange nomader på vejene ind i Østafghanistan i de senere år. Fra slutningen af september 1997 beretter Gorm Pedersen fra en rejse på en FN- og DACAAR-mission sammen med Asta Olesen om så mange nomader på vejene syd for Ghazni og mod Kandahar, som de aldrig tidligere har oplevet.

4. Qatarspecialisten Anie Montigny, Paris, beretter, at Saudi-Arabien må anses for beduinfjendsk i sine moderniseringstiltag og som hjemsted for de islamiske hellige steder næppe har samme behov som Golfstaterne for at fremholde beduinerne som en vigtig del af deres kulturelle arv (fra samtale efteråret 1997).

5. Duranninomaderne i Nord- og Nordvestafghanistan har bibeholdt deres sydafghanske teltform i deres nye vinterområder der, hvor der ej heller var andre traditionelle former af ,det sorte telt". I de fleste områder er de nu den dominerende pashtunnomadegruppe. I Nordvestafghanistan „durraniseres“ østafghanske ghilzaynomader og har her overtaget durannitelttypen (jf. Szabo \& Barfield 1991:32-7 med kort og ill.).

\section{Litteratur}

Beck, L.

1980 The Tribe and State in Revolutionary Iran: The Return of the Qashqa'i Khans. Iranian

Studies 13(1-4):215-55. 
Braae, C.

Heritage Exhibited: A Study of National Culture in the Arabic Gulf Countries Presented through the History and Politics of Museums Practices. Ph.d.-afhandling, Afd. for Etnografi og Socialantropologi, Aarhus Universitet.

Elphinstone, M.

1842 [1815] An Account of the Kingdom of Caubul and its Dependencies in Persia, Tartary, and India. Vol. I-II. London.

Ferdinand, K.

1969a Nomadism in Afghanistan: With an Appendix on Milk Products. I: L. Földes (ed.): Viehwirtschaft und Hirtenkultur. Budapest: Akadémia Kiadó.

1969b Ost-Afghanischer Nomadismus - ein Beitrag zur Anpassungsfähigkeit der Nomaden. I: W. Kraus (ed.): Nomadismus als Entwicklungsproblem. Bochum: Bertelsmann Universitätsverlag.

1993 Bedouins of Qatar. The Carlsberg Foundation's Nomad Research Project. Copenhagen and London/New York: Rhodos, Thames and Hudson.

n.d. Material Culture of Pastoral Nomads: Reflections Based on Arab and Afghan Materials. I: R. Tapper \& K. McLachlan (eds.): Material Culture in Central Asia and the Middle East (tentativ titel). London. (under udgivelse)

Ferdinand, K. et al.

1995-96 Introduction: Danish Nomad Research in Afghanistan. I: B. Frederiksen (ed.): Caravans and Trade in Afghanistan: The Changing Life of the Nomadic Hazarbuz. The Carlsberg Foundation's Nomad Research Project. Copenhagen and London/New York: Rhodos, Thames and Hudson.

Frederiksen, B.

1995/96 Caravans and Trade in Afghanistan: The Changing Life of the Nomadic Hazarbuz. The Carlsberg Foundation's Nomad Research Project. Copenhagen and London/New York: Rhodos, Thames and Hudson.

Glatzer, B.

1977 Nomaden von Gharjistan. Beiträge zur Südasien-Forschung, 22. Wiesbaden: Franz Steiner Verlag.

1982 Processes of Nomadization in West Afghanistan. I: P. C. Salzman (ed.): Contemporary Nomadic and Pastoral People: Asia and the North. Studies in Third World Societies 18. Williamsburg: College of William and Mary.

Khazanov, A. M.

1981 Myth and Paradoxes of Nomadism. Arch. Europ. Sociol. 22:141-53.

1984 Nomads and the Outside World. Cambridge: Cambridge University Press.

Kroeber, A. L.

1947 Culture Groupings in Asia. Southwestern Journal of Anthropology 3:322-30.

Lorimer, J. G.

1908-1915 Gazetteer of the Persian Gulf, 'Omân and Central Arabia. Vol. I-II. Calcutta. (genoptrykt 1970 Shannon: Gregg International Publishers Limited, Farnborough Hants and Irish University Press).

Pedersen, G. 1994

Afghan Nomads in Transition: A Century of Change among the Zala Khan Khel. The Carlsberg Foundation's Nomad Research Project. Copenhagen and London/New York: Rhodos, Thames and Hudson.

Robinson, J. A.

1934 Notes on the Nomad Tribes of Eastern Afghanistan. Government of India Publication. Reprint 1978. Quetta: Nisa Traders. 
Rao, A. (ed.)

1987 The Other Nomads. Køln: Böhlau Verlag.

Safizadeh, F.

1984 Shahsavan in the Grip of Development. Cultural Survival Quarterly 8(1):14-18.

Salzman, P. C.

1972

Multi-Resource Nomadism in Iranian Baluchistan. I: W. Irons \& N. Dyson Hudson (eds.): Perspectives on Nomadism. Leiden: Brill.

Szabo, A. \& T. J. Barfield

1991 Afghanistan: An Atlas of Indigenous Domestic Architecture. Austin: University of Texas Press. 
